\title{
Work-related information needed by farmers for changing to sustainable cropping practices
}

\author{
Elisa Delecourt ${ }^{1} \cdot$ Alexandre Joannon $^{1} \cdot$ Jean-Marc Meynard ${ }^{2}$
}

Accepted: 11 March 2019 / Published online: 10 April 2019

(C) INRA and Springer-Verlag France SAS, part of Springer Nature 2019

\begin{abstract}
Farmers are being urged to change their practices in order to reduce agricultural pollution. These changes may affect working times and organization, and farmers often mention this to explain the difficulties they have in adopting a new practice. But little is known about the work-related changes (e.g., working time, organization, skills) engendered by a change of farming practice, or about the information that farmers need for deciding on and implementing a new practice. In order to design tools to help farmers when adopting more agroecological practices, the objective of this paper is to identify what work-related information is useful to them for changing their practices. We interviewed 16 farmers in France and we then characterized the types of work-related information they had applied. We focused both on changes that were systemic (reducing tillage or diversifying crops) or less systemic (low-volume spraying or mechanical weeding). We performed a qualitative analysis with an iterative method, alternating between gathering data from the farmers and theorizing about what happens on the work front. We then performed a quantitative analysis of the results, based on chi-squared tests, to identify which factors influence farmers' work-related information needs. Our findings showed, for the first time, that farmers apply a wide range of information about work changes, concerning performance of new operations, resources used, work organization and competition between activities, and the arduous or rewarding nature of farm work. We showed that the types of information needed change during the process of introducing a new practice. In the first phase, farmers gather mainly generic information about the focal operation and the resources required. In the next phase, they run innovation experiments, producing their own information on how their work is changing and how to reorganize it. Based on these results, we suggest some paths for designing support tools.
\end{abstract}

Keywords Agroecology $\cdot$ Process of change $\cdot$ Innovation experimentation $\cdot$ Work time $\cdot$ Work organization

\section{Introduction}

In order to reduce agricultural pollution, farmers are adopting new cropping practices such as mechanical weeding or nitratetrapping winter cover crops, or are diversifying their rotations to include pastures, legumes, or low-input species, etc. (Alard et al. 2002; Hauggaard-Nielsen et al. 2012; Pelzer et al. 2012). Introducing new, more sustainable cropping practices can however generate changes to working time and organization

Alexandre Joannon

alexandre.joannon@inra.fr

1 UMR BAGAP, AGROCAMPUS OUEST, ESA, INRA, 65 rue de St Brieuc, CS 84215, 35042 Rennes Cedex, France

2 UMR SADAPT, INRA, AgroParis Tech, Université Paris-Sacaly, 78850 Thiverval-Grignon, France if the implementation date of a new technique is in competition with other interventions on the farm (e.g., sowing cover crops at the time of calving or manure spreading (Paineau et al. 1998)). Or it can require the implementation of collaborative and collective social practices based on knowledge sharing (Sanderson Bellamy and Ioris 2017). Change in work is a factor that farmers often mention to explain the difficulties they encounter in adopting new practices (Paineau et al. 1998; Pfeffer 1992; Sattler and Nagel 2010; Wossink et al. 1997).

Yet few agronomic studies dedicated to technical changes on farms address the work issue. Of those that do, most assess the impact on work by means of multi-criteria analyses which consider work only in terms of its duration (e.g., Karlen et al. 1995; Lithourgidis et al. 2006). Some more ambitious studies have addressed work organization by modeling the farm-level management of a crop or livestock operation (e.g., Aubry et al. 1998; Dounias et al. 1999; Hostiou and Dedieu 2011), for greater understanding and then for advisory purposes. At the 
first International Symposium on Work in Agriculture (November 2016, Brazil), not a single plenary session paper or workshop was devoted to the question of assisting change in agroecological practices (as defined by Wezel et al. 2012). Out of 50 papers, only six addressed the issue of supporting farmers in their change to more sustainable practices. In particular, Coquil et al. (2018) identified some impacts of the adoption of agroecological practices on the work of farmers, advisers, teachers, and researchers, asking: "What changes are needed in the work of Agricultural Knowledge and Innovation Systems (AKIS) actors to better support the agroecological transition?" i.e., the change of practices. Dumont and Baret (2016) examined whether organic farming systems offered better jobs in terms of quality of work than conventional systems. Only the paper by Petit et al. (2016) considered the work-related information that farmers need when changing their practices, showing that existing work organization simulation tools are of limited use for advising farmers. These authors analyzed what farmers said in meetings about changes of practices, and identified needs for information about working time and organization, skills, and costs.

Toffolini et al. (2016) characterized precisely a number of indicators used by farmers to design more sustainable agricultural systems. They also identified a gap between the indicators produced by agronomists and those used by farmers, but they did not focus on work-related indicators. This gap shows the importance of involving farmers in the identification of the information they need during a process of change. Change is described as a multi-step process, including a stage of innovation experiments and not simply the decision to change practices. Most of the research in this respect has been performed by the social sciences (e.g., Collerette et al. 1997), and more recently by agronomists (Chantre 2011, Toffolini et al. 2016, Catalogna et al. 2018).

The aim of our research is to provide agronomists with a framework to analyze farm work, which will allow them to help farmers in changing their practices. By looking at a wide range of changes of farm work generated by the introduction of new, more environment-friendly practices, we aim to identify the types of information on work changes that a farmer can use to decide on and to manage the introduction of a new practice. Based on these results, the end purpose is to put forward useful ideas for designing tools and approaches to help farmers anticipate and adapt to changes in their work when adopting more agroecological practices.

\section{Materials and methods}

\subsection{Choice of farmers}

We selected our case studies in order to sample a variety of technical changes on farms with differing forms of work organization, with the aim of obtaining a certain genericity of results. We interviewed 16 farmers who had undertaken one or more changes to their cropping practices, adopting more environmentally benign methods (Fig. 1), in two agroenvironmentally different French regions: Brittany and Pays de Caux (Table 1). In Brittany, mixed crops (mostly corn and wheat) and livestock systems predominate, while in Pays de Caux, field crops (wheat, beetroot, flax, and potato) are more prevalent and farms are larger. In both regions, agriculture is considered to be responsible for serious environmental damage: surface water pollution by nitrates and phosphates in Brittany, and soil erosion and groundwater pollution by pesticides in Pays de Caux (Joannon et al. 2005; Mabon et al. 2009).

Inspired by the classification proposed by Hill and MacRae (1995), we interviewed farmers who had implemented ambitious changes of practice, to varying degrees. Some of the farmers we interviewed were increasing input efficiency or substituting low-pollution inputs for pollutant ones, aiming to reduce their use of crop protection chemicals (e.g., by low-volume spraying or mechanical weeding) or reducing tillage before sowing (e.g., stubble plowing instead of deep plowing). Other farmers were redesigning their cropping systems by diversifying their rotations (e.g., introducing an alfalfa or a cover crop).

Several studies point out that the organization of work at the farm level is constrained by the means of production (e.g., manpower, plot) and the different activities carried out by an operator (e.g., Aubry et al. 1998, Lorenz and Errington 1991, Joannon et al. 2005, Papy et al. 1988). We selected farmers who had at least one of the following four types of constraint on the organization of their work: a livestock activity, a second occupation (e.g., agricultural contractors or major responsibility in a cooperative), plot constraints (scattered fields, periurban farming), or a large crop area per farm worker. We set

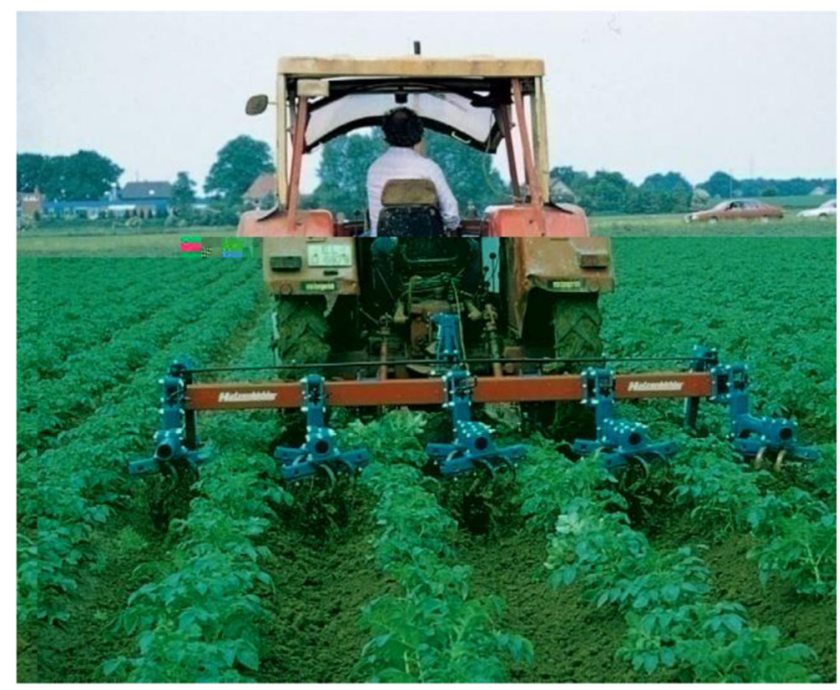

Fig. 1 This farmer has switched to mechanical weeding (source: INRA) 
Table 1 Characterization of the 16 interviews conducted using three selection criteria: change of practice undertaken, farm's location (region), and the presence or not of work organization constraints

\begin{tabular}{|c|c|c|c|c|c|c|c|c|c|c|c|c|c|c|c|c|c|c|}
\hline & & Farm & ners & & & & & & & & & & & & & & & Numbers \\
\hline Selection criteria & & 1 & 2 & 3 & 4 & 5 & 6 & 7 & 8 & 9 & 10 & 11 & 12 & 13 & 14 & 15 & 16 & $16 / 16$ \\
\hline \multirow{3}{*}{$\begin{array}{c}\text { Change of } \\
\text { practice }\end{array}$} & Pesticide use reduction & $\mathrm{X}$ & $X$ & $\mathrm{X}$ & $\mathrm{X}$ & $X$ & & & & & & & & & & & & $5 / 16$ \\
\hline & $\begin{array}{l}\text { Reduced tillage combined } \\
\text { with cover crops }\end{array}$ & & & & $\mathrm{X}$ & & & & & & & & $\mathrm{X}$ & $\mathrm{X}$ & $\mathrm{X}$ & $\mathrm{X}$ & $X$ & $6 / 16$ \\
\hline & Diversification of crop rotations & & & & & $\mathrm{X}$ & $\mathrm{X}$ & $\mathrm{X}$ & $X$ & $X$ & $\mathrm{X}$ & $\mathrm{X}$ & & & & & & $7 / 16$ \\
\hline \multirow[t]{2}{*}{ Location } & Brittany & & & & $\mathrm{X}$ & $\mathrm{X}$ & & & $\mathrm{X}$ & $\mathrm{X}$ & $\mathrm{X}$ & $\mathrm{X}$ & & & & & $X$ & $7 / 16$ \\
\hline & Pays de Caux & $\mathrm{X}$ & $\mathrm{X}$ & $\mathrm{X}$ & & & $\mathrm{X}$ & $\mathrm{X}$ & & & & & $X$ & $\mathrm{X}$ & $\mathrm{X}$ & $\mathrm{X}$ & & $9 / 16$ \\
\hline \multirow{5}{*}{$\begin{array}{l}\text { Labor } \\
\text { constraints }\end{array}$} & Crop area $\geq 60 \mathrm{ha} /$ permanent worker & & $\mathrm{X}$ & $\mathrm{X}$ & & $\mathrm{X}$ & $\mathrm{X}$ & & & & $\mathrm{X}$ & & $\mathrm{X}$ & & $\mathrm{X}$ & & & $7 / 16$ \\
\hline & Area (ha) & 250 & 135 & 270 & 152 & 81 & 170 & 190 & 135 & 60 & 62 & 47 & 158 & 110 & 165 & 180 & 52 & \\
\hline & Livestock activity & & & $\mathrm{X}$ & & $\mathrm{X}$ & & & $\mathrm{X}$ & $\mathrm{X}$ & $\mathrm{X}$ & $\mathrm{X}$ & $\mathrm{X}$ & & $\mathrm{X}$ & & $\mathrm{X}$ & $12 / 16$ \\
\hline & Second occupation & $\mathrm{X}$ & & & & & & $X$ & & & & & & & $\mathrm{X}$ & $\mathrm{X}$ & & \\
\hline & $\begin{array}{l}\text { Plot constraints (peri-urban } \\
\text { area or scattered fields) }\end{array}$ & $\mathrm{X}$ & $\mathrm{X}$ & $\mathrm{X}$ & $\mathrm{X}$ & $\mathrm{X}$ & $\mathrm{X}$ & & $\mathrm{X}$ & $\mathrm{X}$ & $\mathrm{X}$ & & $\mathrm{X}$ & & & $\mathrm{X}$ & $\mathrm{X}$ & $12 / 16$ \\
\hline
\end{tabular}

a threshold of 60 ha per permanent worker, while in France, the average crop area per permanent worker is 45 ha (Agreste 2011).

\subsection{The interviews}

We held 16 semi-structured interviews with farmers, which we recorded on voice recorder and then transcribed. Each interview began with a brief description of the farm (its history, field pattern, labor resources, crops, and animal products) and its current workload peaks (nature, priorities, management). The aim was to understand how the farm functioned overall, so as to be able to question farmers about their choices and how they had implemented their change of practice. The farmers then described how the change had unfolded, in three steps: a description of their current practices, a description of their practices before the change, and a chronology of the change from the old pattern to the new.

When describing the change process, the farmers were asked to explain: (a) what criteria of (dis)satisfaction had prompted them to try new ways of doing things and to adopt or refuse the new ways; (b) what information they had obtained and used, and what they had lacked and would have wanted; and (c) the resulting changes to their work and how they had managed them. In order to obtain detailed replies about changes in work, without influencing the farmers' responses, the first questions were deliberately general. If the farmers had not raised these questions themselves, they were asked about working time and allocation, the workforce, and prioritization and competition between operations or skills. After the interview, a report was drawn up and sent to the farmer for validation. A second interview round was necessary with seven of the farmers, to get more details about the work-related information since the first interview had not been long enough. We took advantage of these meetings to validate with them the first results we had identified from our analysis of the interviews.

\subsection{Analysis of interview data}

\subsubsection{Qualitative analysis}

We analyzed changes in farmers' practices based on their written narrative of these changes, and then asked them to validate our analysis. We drew on the grounded theory method described by Méliani (2013), using an iterative method alternating progressively between: 1) identification of data related to their information use, based on our interviews with farmers, and 2) theorization about what happened on the work front when a farmer undertook a change of practice. To start this theorization, we used the categories of work change identified by Petit et al. (2016): working time, work organization, skills, working conditions, and labor costs. We analyzed each farmer's narrative, with the following questions in mind: "What are the changes in work that have been generated by the change of practice? Is it possible to classify them in one category of work change identified by Petit et al. (2016)? What type of work-related information did the farmer use? When? Before or during the experiment on his/her farm?" Several authors have shown that field testing the new practice is a key stage of the change of practice (Collerette et al. 1997; Chantre 2011; Toffolini et al. 2016; Catalogna et al. 2018). For each farmer interviewed, we identified and categorized the work-related changes, and for each category, we identified the various information items the farmers had used in connection with it.

For example, during an interview, a farmer explained how he had changed his spring crop sowing technique: he stopped 
plowing and tilling several times and replaced these practices by a shallow stubble cultivation and sowing mustard as a cover crop. He also explained that he had bought a new disc seeder. After initial experiments, he found he had good yields and no more pests. He also noted that sowing spring crops was faster and above all less risky, given the limited number of days on which the weather was favorable for sowing. But with this technique, there was an additional step, sowing the cover crop at the end of the summer when it was already a very busy period. According to this narrative, the change of practice had generated several changes in his work. These work-related changes concerned the following categories: the nature and timing of the interventions to be carried out, the equipment to be used, working time, and competition between interventions. To drive these changes, the farmer mobilized different types of information which we codified as follows: (i) the need for a new farm implement (a seeder), (ii) a new intervention to be carried out at the end of summer (mustard sowing), (iii) an increase in working time at the end of summer (cover crop sowing), (iv) new competition between the interventions to be carried out at the end of summer, (v) a decrease in working time during the period of spring crop sowing, and (vi) a reduction in the risks of not being able to sow all spring crops under good climatic conditions. So the farmer mobilized six "information items" related to this change of practice.

To characterize each "information item," we used the iterative method and three criteria: (i) what is the origin of the information used by the farmer, (ii) which operation was concerned (i.e., was it the new practice the farmer wanted to introduce or another one directly or indirectly affected by the change?), and (iii) is the information generic (i.e., valid for a number of farms) or specific to the farm? The "codification" of each farmer's narratives allowed us to (i) establish a categorization of work changes and (ii) identify the type of information items used by farmer for each category of work changes. We validated the categorizations during our second interviews with seven farmers. We then drew up an Excel spreadsheet listing 534 information items identified according to the work change concerned, the moment the information was applied (before or during the tests), the change of practice the farmer was introducing, and the three criteria used.

\subsubsection{Quantitative analysis}

To identify farmers' work-related information requirements, we analyzed the distribution of the information items gathered per category of work change, according to the following: (i) the change of practice undertaken, (ii) farm location (region), (iii) if the information was applied before or during the experiment used, and (iv) the three other criteria cited above. For this, we calculated percentages, which we compared using a chi-squared test to ensure consistence since one information item is counted only once and categories are exclusive. The test was limited to categories for which theoretical sizes were greater than five. Lastly, when we used the criteria to determine whether the information was used before or during the experiment, we excluded seven information items that could not be classified according these criteria. So for part of our analysis, we used 527 information items.

\section{Results and discussion}

\subsection{Four categories of work changes}

We identified a wide range of work changes generated by the introduction of new, more environmentally friendly practices. The changes concerned are as follows: (i) operations to be performed, (ii) resources to be used, (iii) work organization and competition between activities, and (iv) the fulfilling or arduous nature of farm work.

\subsubsection{Changes concerning the farm operations to be performed}

Introducing new practices caused changes in the nature and the number of the operations to be carried out. For example, for one farmer interviewed, introducing a winter cover crop changed the number of observations and treatments needed, such as an anti-slug treatment to protect the next crop, or a roller to prevent cover crop regrowth. So working time and the timing of operations can be affected. Another farmer explained that, in spring, sowing flax is faster with a simplified tillage system because there is one less plowing operation, but it takes place later because the soil has to be less wet for the sowing.

\subsubsection{Changes in resources to be mobilized}

We found changes in the human resources required, in terms of workforce or skills. For one farmer, introducing a cover crop that is sown in late summer increased labor needs. He decided to hire a seasonal worker, as this required no particular training. A new practice may also generate changes in the skills farmers need. For example, three farmers found they lacked skills in observing soil conditions to decide what tillage was required or with regard to nitrogen fertilization after the introduction of a cover crop. Changes in the nature and origin of the material resources to be used were also identified, depending on the availability and skills of the farm's workforce. For example, implements such as a roller had been needed to destroy a cover crop. Whereas one farmer owned one on the farm, and a worker available to drive it, another farmer borrowed a roller from the farm implement cooperative and had it driven by the cooperative's driver. Farmers also identified changes in financial resource requirements. For two 
farmers, reducing tillage had reduced financial costs because plowing was a time-consuming job that had previously been done by a contractor.

\subsubsection{Changes in work organization and competition between activities}

We also found that competition arose between farm tasks or between professional and personal activities. On one farm, harvesting the alfalfa coincided with the sowing of corn, which meant that the two tasks were in competition for use of the farm's tractor. Changes in work organization concerned above all the setting of priorities between the operations to be carried out, or the management of human and material resources. For example, one farmer who had introduced lowvolume spraying, for which the climatic conditions were strict, considered that this operation could not be postponed. So spraying became a priority and a new organization was implemented (e.g., a dedicated tractor permanently hitched to the sprayer, preparation of sprayer and chemicals on the eve of the operation, and possible mutual help with a neighbor).

\subsubsection{Changes regarding the fulfilling or arduous nature of farm work}

The interviews also revealed changes in the farmers' perceptions of how fulfilling or arduous they found their work to be. For example, one farmer explained that before he changed his practices, his work dedicated to crops had been routine: he took care of the livestock and the mowing but delegated crop monitoring and followed the spraying schedule set by the advisor. In changing his practices, he had resumed the crop monitoring work, had been able to reduce the number of treatments, and had acquired more autonomy. Even though his working time had increased, he did not consider this as a problem because the work was rewarding. Changes might also involve new arduous physical tasks such as night work, for example. According to one farmer interviewed, low-volume spraying had to be done late in the evening or early in the morning, sometimes as early as 4 a.m. But arduousness could be offset by the comfort of a new spraying tractor equipped with GPS and an automated boom. Mental effort could also make work arduous. One farmer found no-till sowing of spring crops more stressful because the best time to sow varies widely from year to year, the conditions are stricter, and sowing must be done promptly, in a very short time lapse, so as not to miss the window of opportunity.

\subsubsection{The same diversity regardless of change undertaken and farm location}

There seems to be no mention in the agronomy literature of this wide diversity of work changes generated by the introduction of new, more environment-friendly cropping practices. However, livestock scientists studying farm work have made comparable findings. They identify three aspects of work: (i) technical: labor, equipment, working time; (ii) organizational: distribution of tasks among the workforce and over time; and (iii) subjective: the meaning a worker gives to their work, which may be a source of pleasure or pain (Kling-Eveillard et al. 2012; Fiorelli et al. 2010).

Table 2 shows that there is very little difference between types of change of practice, or between farm locations, in the relative percentages of information items relating to the different work change categories. Statistical analysis shows no significant differences in the breakdown of numbers of information items, between those concerning the change of practice undertaken, and those concerning the farm's location (Table 2). We also found that farmers used more information for changes concerning the performance of operations (66 to $70 \%$ for changes of practices and for location, on average) than for those concerning the use of resources (14 to 18\%), work organization and competition (13 to $14 \%$ ), or the rewarding or arduous nature of the work (3\%). The change of practice involved and the location of the farm had no significant impact on the pattern of information use.

\subsection{The use of work-related information}

In this part, we analyze how information related to the four categories of work changes identified were used by farmers during the process of changing practices, by analyzing differences before and during experiments.

\subsubsection{Innovation experimentation as the key stage for information use}

All the farmers interviewed had experimented with the new practice on a strip of land, a field or the farm in general, before deciding whether to adopt it. According to them, these innovation experiments played an essential role in their adaptation to the work changes generated by the new practice and their subsequent reorganization of the farm work. One farmer, for example, said he could not have known in advance how to organize the work when he switched to a system with more grazing. Another one said that before they experimented with low-volume spraying, farmers should be advised to keep a tractor permanently hitched and the tank full. But he also said it was always different from one farm to another, and that it was by experimenting and seeking solutions to problems as they arose that one could gradually reorganize the work, i.e., "who does what when," depending on each year's weather conditions. Several authors have identified innovation experiments as the key stage in the process of changing to a new practice (e.g., Collerette et al. 1997; Chantre 2011; Toffolini et al. 2016; Catalogna et al. 2018). 
Table 2 Breakdown of numbers of information items gathered per type of work change, by change of practice undertaken (pesticide use reduction, reduced tillage combined with cover crops, or diversification or crop rotation), and farm location (Brittany or Pays de Caux). No significant differences according to the change of practice undertaken (chi-squared test $P$ value $=0.971$ ) or according to farm location (chisquared test $P$ value $=0.7643$ )

\begin{tabular}{|c|c|c|c|c|c|c|}
\hline \multirow{2}{*}{$\begin{array}{l}\text { Type of work-related } \\
\text { change }\end{array}$} & \multicolumn{3}{|c|}{ Change of practice } & \multicolumn{2}{|c|}{ Farm location } & \multirow{2}{*}{$\begin{array}{l}\text { Total numbers of } \\
\text { information items }\end{array}$} \\
\hline & $\begin{array}{l}\text { Pesticide use } \\
\text { reduction }\end{array}$ & $\begin{array}{l}\text { Reduced tillage combined } \\
\text { with cover crops }\end{array}$ & $\begin{array}{l}\text { Diversification of } \\
\text { crop rotations }\end{array}$ & Brittany & Pays de Caux & \\
\hline Performance of operations & $131(69 \%)$ & $108(66 \%)$ & $125(69 \%)$ & $151(66 \%)$ & $213(70 \%)$ & 364 \\
\hline Resources to be mobilized & $28(15 \%)$ & $30(18 \%)$ & $26(14 \%)$ & $40(18 \%)$ & $44(14 \%)$ & 84 \\
\hline Work organization and competition & $25(13 \%)$ & $21(13 \%)$ & $25(14 \%)$ & $30(13 \%)$ & $41(13 \%)$ & 71 \\
\hline Rewarding and arduous nature of work & $5(3 \%)$ & $5(3 \%)$ & $5(3 \%)$ & $7(3 \%)$ & $8(3 \%)$ & 15 \\
\hline Total numbers of information items & $189(100 \%)$ & $164(100 \%)$ & $181(100 \%)$ & $228(100 \%)$ & $306(100 \%)$ & 534 \\
\hline
\end{tabular}

In Table 3, we found differences in the information used, before and during experimentation. Before they had tried a new technique, farmers used less information about work organization and competition, or about the rewarding or arduous nature of a task (respectively only $16 \%$ and $20 \%$ ), whereas the numbers of information items were more similar for changes in operations to be carried out ( $42 \%$ before and $58 \%$ during innovation experimentation) and resources to be mobilized (55\% before and $44 \%$ during innovation experimentation). According to our statistical comparison test results, these differences of distribution are significant: the types of work-related information used by a farmer shift during the process of changing a farming practice. As far as we know, no other scientific study has yielded a similar result.

\subsubsection{Three criteria for characterizing the information used before and during innovation experimentation}

The interviews brought to light wide differences in the information farmers were using, in terms of the following: (i) how the information was obtained and where it came from; (ii) how complete it was: whether it concerned one action or several related actions; and (iii) whether it was specific to the particular farm or generic.
Ways of information acquisition The work-related information farmers used in the process of changing their practices had been obtained in various ways. Some came from outside sources: agricultural advisors, the farming press, training courses the farmer attended, or other farmers (a neighbor, other members of a mutual aid group, e.g., for ensiling corn or sharing equipment, or at support meetings with other farmers changing their practices). We had already found that farmers sought information by attending meetings with other farmers aiming to change their farming methods, organized by agricultural advisory services (Petit et al. 2016). Information obtained from outside sources was reinterpreted in light of the farmer's experience. Cerf and Magne (2007) have also shown the distinction between internal and external sources of information used when changing farm practices, and the variety of sources (oral exchanges, different media etc.).

Farmers also produce information about work-related changes themselves, during innovation experiments. Some information is produced by observation in the course of the work. For example, when trying out low-volume spraying for the first time, a farmer noticed that preparing a low-volume mix of chemicals took much longer than preparing a full-dose treatment. Information is also produced by farmers analyzing or reasoning from their observations, their past experience, or externally sourced information. For example, introducing an early-sown cover
Table 3 Breakdown of numbers of information items gathered per work change category by period (before or during a farmer's innovation experimentation with a new technique): significant differences between information item distribution by period (chi-squared test $P$ value $=6.959^{-06}$ )

\begin{tabular}{llll}
\hline Type of work-related change & $\begin{array}{l}\text { Before innovation } \\
\text { experimentation }\end{array}$ & $\begin{array}{l}\text { During innovation } \\
\text { experimentation }\end{array}$ & $\begin{array}{l}\text { Total numbers per } \\
\text { line* }\end{array}$ \\
\hline Performance of operations & $150(42 \%)$ & $210(58 \%)$ & $360(100 \%)$ \\
$\begin{array}{l}\text { Resources to be mobilized } \\
\text { Work organization and }\end{array}$ & $46(55 \%)$ & $38(45 \%)$ & $84(100 \%)$ \\
$\quad$ competition & $11(16 \%)$ & $57(84 \%)$ & $68(100 \%)$ \\
$\begin{array}{c}\text { Rewarding and arduous } \\
\text { natureof work }\end{array}$ & $3(20 \%)$ & $12(80 \%)$ & $15(100 \%)$ \\
$\begin{array}{c}\text { Total numbers per column* } \\
\text { Pal }\end{array}$ & 210 & 317 & 527 \\
\hline
\end{tabular}

*Seven information items could not be classified by period 
crop caused competition with manure spreading and liming operations. To limit this end-of-summer competition, the farmer prioritized the operations by reasoning as follows: a wheat crop is less sensitive to soil compaction than a spring crop sown after an autumnal cover crop (emergence and yield are both satisfactory); so the farmer gives priority to sowing the cover crop; manuring and liming, which take place before wheat sowing, can be done later, when the weather has deteriorated and the soil is wetter. This type of information acquisition can be compared to the process of experiential learning, described by Kolb (1984) as an individual's creation of knowledge through practical experience, observation, and analysis.

Information relating to "focal," "ancillary," or "affected" operations Some of the work-related information that farmers use concerns only one operation, which we shall call the "focal" one, but some concerns interactions with other operations which may be "ancillary" or "affected". For example, with a low-volume protection treatment, the focal operation is the actual spraying; the ancillary operations are those that precede and follow it, e.g., crop monitoring and preparing and cleaning the sprayer; and affected operations are others that have to change, e.g., the calves are fed later because lowvolume spraying has to be done early in the morning. Most of the indicators farmers use are described in the literature in terms of spatial scale, mainly that of the field (Toffolini et al. 2016), rather than the operation concerned. But these authors do suggest making a distinction between the scale of the "object of the action" and that of "other objects"- a classification similar to ours.

Generic vs. specific information What we refer to as generic information is any information relevant to more than one farm, such as the reference speed of a farm machine. What we call specific information is specific to a particular farm or farmer, such as the same machine's speed as recorded by the farmer in his/her small, non-rectangular fields. Generic information can be understood by most people and can be used by farmers irrespective of the characteristics of their farm or its agroenvironmental context. We have found only one study that proposes a similar characterization. Duru (2013), seeking ideas for use in field tool design, differentiated between generic and specific knowledge in describing the knowledge content of two grassland management tools.

\subsubsection{Patterns of information used before vs. during innovation experimentation}

In this part we analyze, for each of the four categories of work change, if there are differences in the pattern of work-related information, depending on the process of change (before vs during the experiment), the specificity of information items, and the operation concerned ("focal," "ancillary," or "affected"). We analyze these differences for each of the four categories of work change.

Categories: operations to be performed and resources to be mobilized Most of the information that farmers used before experimentation with a new technique concerned the operations to be performed and the resources to be used. The great majority of these related to focal operations $(73 \%$ and $63 \%$ for both categories-Table 5), and was not specific to the particular farm or farmer $(90 \%$ and $72 \%$ for both categoriesTable 4). This information came primarily from outside sources, especially the information that only concerns focal operations. Any specific information used before experimentation was knowledge which the farmer had acquired previously. During innovation experimentation, the information used related in fairly similar proportions to focal, ancillary, and affected operations (28 to $32 \%$ ). Most of this information was farm-specific and produced during the experimentation process itself $(76 \%)$. For example, one farmer found that in order to stop systematically spraying his crops, it was essential to monitor them daily, but that this did not take more time because he could do it while taking his cows to pasture. Farmers also used externally sourced information during their innovation experimentation, mainly targeted information they sought out to help them adapt to a work-related change they had identified. For example, one farmer found, during experimentation, that harvesting alfalfa for silage took too long, required a lot of manpower, and competed with other operations, so he sought out generic information about the wrapped bale system (harvest period, equipment, possibility and cost of outsourcing, etc.).

Category: work organization and competition Both before and during innovation experimentation, information on competition between tasks generally concerned affected operations much more than focal and/or ancillary ones (Table 5around $90 \%$ vs less than 10\%). Changes in work organization and competition were considered farm-wide, not only in the field where the new operation is performed.

Before experimentation, most information of this kind was a combination of knowledge the farmer already had, and information about the new operations and resource requirements obtained from outside sources. For example, to identify ways of reducing competition during spring work peaks caused by the introduction of hoeing, a farmer used information about working time and efficiency conditions for hoeing (exogenous data) and for spraying (from his own knowledge).

During experimentation, farmers acquired information in two ways. They produced it from their own observations and analysis (e.g., a farmer found that the harvest of a newly introduced forage crop competes for manpower with corn 
Table 4 Breakdown of numbers of information items gathered per work change category according to the period (before or after innovation experimentation) and to the specific or generic nature of the information. There are significant differences between information item distributions per work change category before innovation experimentation (chi-squared test $P$ value $=1.902^{-08}$ ) and during tests (chi-squared test $P$ value $=7.176^{-02}$ )

\begin{tabular}{|c|c|c|c|c|c|c|}
\hline \multirow[t]{4}{*}{ Type of work-related change } & \multicolumn{6}{|l|}{ Period } \\
\hline & \multicolumn{3}{|c|}{ Before innovation experimentation } & \multicolumn{3}{|c|}{ During innovation experimentation } \\
\hline & \multicolumn{6}{|c|}{ Information type } \\
\hline & Generic & Specific & $\begin{array}{l}\text { Total number of items } \\
\text { before innovation } \\
\text { experimentation }\end{array}$ & Generic & Specific & $\begin{array}{l}\text { Total number of items } \\
\text { during innovation } \\
\text { experimentation }\end{array}$ \\
\hline Performance of operations & $135(90 \%)$ & $15(10 \%)$ & $150(100 \%)$ & $50(24 \%)$ & $160(76 \%)$ & $210(100 \%)$ \\
\hline Resources to be mobilized & $33(72 \%)$ & $13(28 \%)$ & $46(100 \%)$ & $9(24 \%)$ & $29(76 \%)$ & $38(100 \%)$ \\
\hline Work organization and competition & $4(36 \%)$ & $7(64 \%)$ & $11(100 \%)$ & $7(12 \%)$ & $50(88 \%)$ & $57(100 \%)$ \\
\hline Rewarding or arduous nature of work $* *$ & $0(0 \%)$ & $3(100 \%)$ & $3(100 \%)$ & $0(0 \%)$ & $12(100 \%)$ & $12(100 \%)$ \\
\hline Total number of information items per column* & 172 & 38 & 210 & 66 & 251 & 317 \\
\hline
\end{tabular}

*Seven information items could not be classified by period

**No statistical test because numbers too small

sowing), and they sought out new information to solve problems and adapted it (e.g., to see if the forage harvest could be done with a mutual aid group, or if corn sowing could be postponed without a negative impact on the yield). Information at this stage was more often produced by the farmer than gathered from outside, and was consequently mostly farm-specific (88\%-Table 4).

Category: fulfilling or arduous nature of the work All the information that farmers use on the relatively fulfilling or arduous nature of a task is specific to themselves and to their farm (Table 4), since it concerns their own feelings about changes. This information concerns focal as well as ancillary and affected operations both before and during experiments (Table 5-25 to $42 \%$ ).

Before a farmer experiments with a new technique, information of this kind is based on comparing values, feelings, own past experience, and the exogenous information that he or she collects (e.g., a farmer sought out information on alternatives to plowing because that was a job he or she found slow, repetitive, and boring). During experimentation, farmers noted changes in their subjective experience of their work. For example, four farmers found that crop monitoring to reduce their use of chemicals was a pleasant task that also afforded them more independence in decision-making. During experiments, farmers also obtained information from outside
Table 5 Breakdown of numbers of information items gathered per work change category by operation concerned (focal, ancillary, or incidentally affected) and by period: significant differences between information item distributions per work change category before innovation experimentation (chi-squared test $P$ value $=7.945^{-08}$ ) and during experimentation (chi-squared test $P$ value $=3.389^{-12}$ )

\begin{tabular}{|c|c|c|c|c|c|c|c|c|}
\hline \multirow[t]{4}{*}{ Type of work-related change } & \multicolumn{8}{|l|}{ Period } \\
\hline & \multicolumn{4}{|c|}{ Before innovation experimentation } & \multicolumn{4}{|c|}{ During innovation experimentation } \\
\hline & \multicolumn{8}{|c|}{ Operation concerned } \\
\hline & Focal & Ancillary & Affected & Total numbers & Focal & Ancillary & Affected & Total numbers \\
\hline Performance of operations & $110(73 \%)$ & $21(14 \%)$ & $19(13 \%)$ & $150(100 \%)$ & $80(38 \%)$ & $72(34 \%)$ & $58(28 \%)$ & $210(100 \%)$ \\
\hline Resources to be mobilized & $29(63 \%)$ & $8(17 \%)$ & $9(20 \%)$ & $46(100 \%)$ & $13(34 \%)$ & $13(34 \%)$ & $12(32 \%)$ & $38(100 \%)$ \\
\hline Work organization and competition & $1(9 \%)$ & $0(0 \%)$ & $10(91 \%)$ & $11(100 \%)$ & $5(9 \%)$ & $3(5 \%)$ & $49(86 \%)$ & $57(100 \%)$ \\
\hline Rewarding and arduous nature of work $* *$ & $1(33 \%)$ & $1(33 \%)$ & $1(33 \%)$ & $3(100 \%)$ & $3(25 \%)$ & $4(33 \%)$ & $5(42 \%)$ & $12(100 \%)$ \\
\hline Total number of information items per column* & 141 & 30 & 39 & 210 & 101 & 92 & 124 & 317 \\
\hline
\end{tabular}

*Seven information items could not be classified by period

**No statistical test because numbers too small 
sources, when they looked for ways to make a job less arduous (e.g., a new GPS-equipped tractor can make the night work necessary for low-volume spraying less arduous).

\subsection{Work-related information farmers lacked for anticipating and adapting to changes}

Based on the previous results and on the interviews in which farmers specifically discussed the lack of information they had identified, we identify how tools could be designed to better support farmers when they change their practices.

\subsubsection{Working time in the field: insufficient and misleading information}

Working time is often mentioned as a hindrance to the adoption of new, more agroecological practices (Sattler and Nagel 2010), but three farmers expressed clear reservations about that claim. One of them said, "When a farmer says he can't change because he doesn't have the time, it's a pretext. When you decide to make a change, you manage to find solutions and the time you need." Six farmers explained that reducing working time was a driver of their decision to reduce tillage or to introduce low-volume spraying, but when they ran experiments, they all found that they saved less time than they had hoped to. For example, farmers experimenting with lowvolume spraying found that although the spraying operation in the field was quicker, more such operations were needed, and also a lot of preparation. Two farmers whose fields were over $30 \mathrm{~km}$ apart found that travel time was substantially greater; they considered this to be lost time. In this example, the farmers had based their decision on an underestimation of working time because they had only considered the machine time per hectare, for the focal operation (speed $\times$ area to be sprayed). This estimation was easy to obtain, but it appeared insufficient (as it took no account of travel time or preparation time) and also deceptive. It was not so much working time that caused problems for farmers, as the operation's timing and its degree of flexibility, because it might cause an accumulation of competing operations to be done in the same period. For example, one farmer who was spraying low volumes of herbicide wanted to introduce hoeing. He explained this choice by the constraints of scheduling and the conditions for lowvolume spraying which gave this operation absolute priority over other farm work and personal activities. So he had decided to experiment with hoeing because although this operation takes more machine time per hectare, it is done outside peak times, and with more flexibility in the scheduling.

This shows the value of supplying farmers with more information than just working time in the field - for instance information on the scheduling of focal, ancillary, and affected operations - to enable them to foresee competition between operations and so help them change their practices. The
Atelage work organization model (Madelrieux et al. 2006), which was designed to produce knowledge about how livestock farmers assign tasks to their workers, offers an interesting approach for thinking about affected operations as well as the focal operation. Madelrieux et al. (2006) suggest analyzing forms of organization at different temporal scales (day, month, year), and characterizing farm operations in terms of their rhythm, whether daily (e.g., milking) or not (e.g., sowing silage corn).

\subsubsection{Lack of information for anticipating work-related changes before innovation experimentation}

The information that farmers lacked and would have wanted before trying a new technique concerned the following: (i) the number of runs required to obtain the desired result with a new technique, (ii) ancillary operations to be carried out and other operations affected, and (iii) the fulfilling or arduous nature of the work.

An estimation of the number of runs is important because it affects not only the working time but also the timing of the operation and potential competition with other tasks. It can call into question the decision to adopt the new technique. For example, one farmer who experimented with strip tilling for beet found that a single run did not produce a suitable seedbed and that three runs were needed, at intervals. This meant more tillage time and later sowing, which was then in competition with other spring operations in a more acute work peak-so much so that the farmer regretted his decision to introduce the technique, claiming that it had been based on insufficient information.

Some farmers also said they needed more information about ancillary and affected operations, stressing that they had difficulty finding such information from external sources. One farmer wanting to introduce cover crops wondered about how to manage nitrogen fertilization on his flax crop. He found little information: "The advice is too general and not very appropriate." To find out, he had to experiment and share feedback with other farmers. Another farmer said that in his view, the advisory bodies were 10 years behind the times as regards innovative techniques for reducing tillage, and that as a result farmers exchanged information among themselves, mainly through Internet forums. These findings match those of Gerber et al. (1996), quoted by Kummer et al. (2010), who suggest that the lack of reference studies on new organic practices is driving farmers to develop a culture of experimentation to innovate and to find answers to their own questions.

The farmers interviewed also stressed the importance of knowing how rewarding, arduous, or stressful the work would be with a new practice. All too often they only found out when they implemented the practice. Some 
farmers said they would have taken a different view of reduced tillage if they had known that spring sowing would be more stressful because it had to take place later, in a very short time window. Others said that monitoring crops to reduce spraying did take time but was a pleasant job. They explained that it represented a return to basic farming skills, involving agronomic thinking and independent decision-making - skills which they had lost by delegating crop monitoring and merely carrying out the spraying program determined by an outside technician. The need to gather such information before experimenting is thus particularly important, as these changes can have a major influence on the decision to adopt a new practice.

One possible avenue for making such information available would be to facilitate communication between farmers who have already experimented with a new technique and those who are considering it. However, when we were validating work change categories with seven of the farmers interviewed, four said they had never talked about or even identified their work changes in that way. The fact that work information is tacit (and also private or taboo, as shown in livestock farming by Kling-Eveillard et al. (2012)) can make it difficult for farmers to discuss it. According to Nonaka et al. (1994), person-to-person transmission of tacit knowledge can be achieved through a process of "socialization," that is, via observation, imitation, or experience sharing. These authors also point out that oral transmission is possible only between people who have the same language and the same real-life experience. So farmers' tacit knowledge needs to be made explicit to facilitate communication among them. Kling-Eveillard et al. (2012) recommend using self-diagnosis questionnaires to "break the ice" and get farmers talking about their work and particularly its arduousness.

\subsubsection{Innovation experimentation to produce missing knowledge and reorganize farm work}

As most of the information gathered before experimentation is generic in nature (see 2.2.3) and many work changes are unknown or hard to identify before the farmer runs an experiment (see 2.3.2), on-farm experimentation seemed to be indispensable for producing the missing farm-specific information. This was particularly the case for changes affecting work organization and competition. One farmer even insisted that it was no use gathering information about work organization before running an experiment (see 2.2.1 and 2.2.3). According to Kolb (1984), cited by Chantre (2011), experiential learning has a very strong impact in terms of cognitive changes and is even the most powerful mechanism for individual learning.

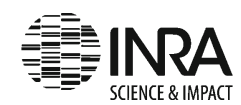

More precisely, to reorganize work in a suitable way, we found that farmers needed information to help them assess the implications of their prioritizations and resource allocations for the performance of all operations on the farm during the same period. They got this information through innovation experimentation. One farmer, for example, needed information to determine that, on his farm, "making grass silage in May should take priority over sowing corn, because the risk of a poor harvest is less with late corn sowing than with late silage making." This information was indispensable for establishing a satisfactory work organization, and the farmer obtained it by a series of experiments, varying the order of operations and the resource allocation, notably for a skilled workforce (e.g., mutual aid group for grass silage, outsourcing corn sowing). He had also used ideas from the information he had gathered (e.g., replacing maize with sorghum, which reaches maturity faster so that sowing need not coincide with the silage grass harvest), and analyzed his experiment results according to his own criteria (e.g., the amount of weeds he considered tolerable in a maize field, and desired forage quality).

Papy et al. (1988) and Aubry et al. (1998) identified the importance of task prioritization and trade-off rules for organizing farm work, but they did not describe how farmers established these rules. The farmers we interviewed confirmed that they made their own rules, based on their innovation experiments. However, some stressed that they felt illequipped for assessing and comparing the consequences of their prioritization and resource allocation, and for finding alternative ideas to experiment with. Six farmers spoke of a very slow process in which the most satisfactory work organization "gradually became obvious," as they put it, after several cropping seasons. Kummer et al. (2010) showed that farmers' experiments enabled them to produce local knowledge and to develop their adaptive capabilities when changing practices, but they did not mention the role of innovation experimentation for establishing a new work organization.

One way to help farmers produce the information they lack would be to make innovation experimentation easier. Guides to monitoring and analyzing work changes could be envisaged to complement existing measures which encourage farmers to experiment with innovations but do not help them evaluate and compare the consequences of their prioritization and resource allocation. The testimony of one farmer who had received collective and individual assistance for reducing fungicide use suggests an approach to help farmers learn a method of analysis. The farmer explained that during the experiments, he had the benefit of feedback from farmers in the group he was a member of, as well as individual assistance from the group's advisor. The advisor's presence made him take the time to monitor (regularly, and not just at the field's edge), ask himself the right questions (Rust outbreak? Weather? How risky is it 
not spraying?), and explicitly formulate his interpretation of his observations (e.g., "No rust outbreak and dry weather, so it seems possible to postpone the first fungicide application without a negative effect on yield, but it is necessary to watch out for rust and be ready to act if need be").

\section{Conclusion}

In this study, 16 farmers were interviewed to find out what types of work-related information they used for changing their farming practices. We have shown that farmers find out about a range of work-related changes connected with the following: (i) the performance of the new operations, (ii) the resources to be used, (iii) work organization and competition between tasks, and (iv) the arduous or rewarding nature of the work. As suggested by the literature on practice change processes, we have shown that the ways in which information is used differ between before the experimentation and during it. But we have not identified differences between types of change of practice or between farm locations.

Before innovation experimentation, farmers mainly gather generic information, from external sources, about the focal operations to be performed and the resources to be used. Instead of a misleading estimate of the increase or reduction in working time in the field, they need information that would help them anticipate changes to their work by identifying ancillary operations and other operations affected by the change in practice, or the number of runs required to obtain a desired result, or the likelihood that work peaks would be aggravated or alleviated. We have also shown that during innovation experimentation, farmers produce farm-specific knowledge about all types of work changes and also gather generic information on the new operations to be performed and the resources required. They need to run experiments to discover the consequences of their prioritizations and resource allocations, so that they can organize their work in a satisfactory way.

All of these are ideas to be explored for designing tools other than calculators of field working time, to help farmers change their practices towards agroecology. We believe that these new tools should inform farmers differently about a variety of work changes, depending on when they are used (before or during innovation experiments). These tools could be used by farmers alone, in a group, or with an agricultural adviser.

Acknowledgments We thank all the farmers who agreed to be interviewed.

Funding information This study was financially supported by the LoireBrittany and Seine-Normandie water agencies.

\section{Compliance with ethical standards}

Conflict of interest The authors declare that they have no conflict of interest.

\section{References}

Agreste (2011) Recensement agricole 2010 en France métropolitaine. Agreste Primer Ministère de l'agriculture et de l'Alimentation, http://agreste.agriculture.gouv.fr/IMG/pdf_primeur266-2.pdf

Alard V, Beranger C, Journet M (2002) A la recherche d'une agriculture durable Etude de systèmes herbagers économes en Bretagne. Inra Editions, Paris

Aubry C, Papy F, Capillon A (1998) Modelling decision-making processes for annual crop management. Agric Syst 56(1):45-65

Catalogna M, Dubois M, Navarrete M (2018) Diversity of experimentation by farmers engaged in agroecology. Agron Sustain Dev 38(50). https://doi.org/10.1007/s13593-018-0526-2

Cerf M, Magne M-A (2007) Comment les agriculteurs mobilisent-ils des interventions de développement? Activites 04(1). https://doi.org/10. 4000/activites. 1430

Chantre E (2011) Apprentissages des agriculteurs vers la réduction d'intrants en Grandes Cultures: Cas de la Champagne Berrichonne de 1'Indre dans les années 1985-2010. Sciences agricoles. AgroParisTech, https://pastel.archives-ouvertes.fr/pastel-01002797/ document

Collerette P, Delisle G, Perron R (1997) Le changement organisationnel: théorie et pratique. Presses de l'Université du Québec

Coquil X, Cerf M, Auricoste C, Joannon A, Barcellini F, Cayre P, Chizallet M, Dedieu B, Hostiou N, Hellec F, Lusson JM, Olry P, Omon B, Prost L (2018) Questioning the work of farmers, advisors, teachers and researchers in agro-ecological transition. A review. Agron Sustain Dev 38:47. https://doi.org/10.1007/s13593-0180524-4

Dounias I, Aubry C, Capillon A (1999) Decision-making processes for crop management on African farms, modelling from a case study of cotton crop in northern Cameroon. Agric Syst 73:233-260. https:// doi.org/10.1016/S0308-521X(01)00077-4

Dumont A, Baret P (2016) What are the differences in quality of work between vegetable growers in agroecological and in conventional systems? In: International symposium on work in agriculture, Maringa Brazil, Nov.8-11th 2016. p 10

Duru M (2013) Combining agroecology and management science to design field tools under high agrosystem structural or process uncertainty: lessons from two case studies of grassland management. Agric Syst 114:84-94. https://doi.org/10.1016/j.agsy.2012.09.002

Fiorelli C, Dedieu B, Porcher J (2010) Un cadre d'analyse des compromis adoptés par les éleveurs pour organiser leur travail. Cahiers Agricultures 19(5):8. https://doi.org/10.1684/agr.2010.0424

Gerber A, Hoffmann V, Kügler M (1996) Das Wissensystem im Ökologischen Landbau in Deutschland: Zur Entstehung und Weitergabe von Wissen im DiffusionprozeB. Bericht über Landwirtschaft 74:36

Hauggaard-Nielsen H, Mundus S, Jensen ES (2012) Grass-clover undersowing affects nitrogen dynamics in a grain legume-cereal arable cropping system. Field Crop Res 136:23-31. https://doi.org/ 10.1016/j.fcr.2012.07.001

Hill S, MacRae R (1995) Conceptual framework for the transition from conventional to sustainable agriculture. J Sustain Agric 7(1):7

Hostiou N, Dedieu B (2011) A method for assessing work productivity and flexibility in livestock farms. Animal 6(05):852-862. https:// doi.org/10.1017/s1751731111002084 
Joannon A, Papy F, Martin P, Souchère V (2005) Planning work constraints within farms to reduce runoff at catchment level. Agric Ecosyst Environ 111:13-20. https://doi.org/10.1016/j.agee.2005. 04.021

Karlen D, Duffy M, Colvin T (1995) Nutrient, labor, energy and economic evaluations of two farming systems in Iowa. J Prod Agric 8(4): 461-546

Kling-Eveillard F, Cerf M, Chauvat S, Sabatte N (2012) Le travail sujet intime et multifacette première recommandations pour l'aborder dans le conseil en élevage. INRA Prod Anim 25(2):9

Kolb D (1984) The process of experiential learning. In: Experiential learning experience as the source of learning and development. Prentice Hall, Englewood Cliffs, p 18

Kummer S, Aigelsperger L, Milestad R, Chowdhury A, Vogl C (2010) Knowledge systems, innovations and social learning in organic farming - an overview. Paper presented at the 9th European IFSA Symposium, Vienna (Autria), Jul. 4-6 2010

Lithourgidis AS, Dhima KV, Damalas CA, Vasilakoglou IB, Eleftherohorinos IG (2006) Tillage effects on wheat emergence and yield at varying seeding rates, and on labor and fuel consumption. Crop Sci 46(3):1187-1192. https://doi.org/10.2135/ cropsci2005.09-0321

Lorenz C, Errignton A (1991) Achieving sustainability in cropping systems: the labour requirements of a mulch rotation system in Kalimantan, Indonesia. Trop Agric 68(3):249-254

Mabon F, Raimbault T, Moreau P, Devienne S, Delaby L, Durand P, Ruiz L, Vertes F (2009) Concilier efficacité technico-économique et environnementale des exploitations agricoles en zone vulnérable : apport du diagnostic agraire. Fourrages 199:373-388

Madelrieux S, Dedieu B, Dobremez L (2006) ATELAGE: un modèle pour qualifier l'organization du travail dans les exploitations d'élevage (ATELAGE: Modelling to qualify work organization in livestock farming systems). Prod Anim 19(1):47-57

Méliani V (2013) Choisir l'analyse par théorisation ancrée : illustration des apports et des limites de la méthode. Recherches qualitatives Hors série $n^{\circ} 15: 18$

Nonaka I, Byosiere P, Borucki C, Konno N (1994) Organizational knowledge creation theory: a first comprehensive experiment. Int Bus Rev 3(4):15

Paineau F, Demazeau E, Bel M (1998) Quels éléments conditionnent le regard des agriculteurs sur l'environnement et l'adoption des pratiques plus respectueuses de l'environnement? Courrier de l'environnement de l'INRA 35:65-70

Papy F, Attonaty J, Laporte C, Soler LG (1988) Work organization simulation as a basis for farm management advice. Agric Syst 27:295305. https://doi.org/10.1016/0308-521X(88)90037-6

Pelzer E, Bazot M, Makowski D, Corre-Hellou G, Naudin C, Al Rifaï M, Baranger E, Bedoussac L, Biarnès V, Boucheny P, Carrouée B, Dorvillez D, Foissy D, Gaillard B, Guichard L, Mansard M-C, Omon B, Prieur L, Yvergniaux M, Justes E, Jeuffroy M-H (2012) Pea-wheat intercrops in low-input conditions combine high economic performances and low environmental impacts. Eur J Agron 40:39-53. https://doi.org/10.1016/j.eja.2012.01.010

Petit E, Joannon A, Meynard J (2016) Do work simulation tools help farmers to change crop practices? Paper presented at the International Symposium on Work in Agriculture, Maringa Brazil, Nov. 8-11th 2016. p 10

Pfeffer M (1992) Labor and production barriers to reduction of agricultural chemical inputs. Rural Sociol 57(3):347-362

Sanderson Bellamy A, Ioris AAR (2017) Addressing the knowledge gaps in agroecology and identifying guiding principles for transforming conventional agri-food systems. Sustainability 9(3):330. https://doi. org/10.3390/su9030330

Sattler C, Nagel U (2010) Factors affecting farmers' acceptance of conservation measures - a case study from north-eastern Germany. Land Use Policy 27:70-77. https://doi.org/10.1016/j.landusepol. 2008.02.002

Toffolini Q, Jeuffroy M-H, Prost L (2016) Indicators used by farmers to design agricultural systems: a survey. Agron Sustain Dev 36(1). https://doi.org/10.1007/s13593-015-0340-Z

Wezel A, Casagrande M, Celette F, Vian JF, Ferrer A, Peigné J (2012) Agroecological practices for sustainable agriculture. Agron Sustain Dev 34(1). https://doi.org/10.1007/s13593-013-0180-7

Wossink G, De Buck A, Van Niejenhuis J, Haverkamp H (1997) Farmers perceptions of weed control techniques in sugar beet. Agric Syst 55(3):409-423. https://doi.org/10.1016/S0308-521X(96)00097-2

Publisher's note Springer Nature remains neutral with regard to jurisdictional claims in published maps and institutional affiliations. 